\title{
Mapping Social and Economic Vulnerability in Forest and Peatland Fire Disaster in Bengkalis Regency, Riau Province
}

\author{
Eko Ahmad Riyanto \\ Master Program of Geo-Information for Spatial Planning and Disaster Management, \\ Post Graduate School, Gadjah Mada University \\ Corresponding E-mail: ekoahmadriyanto@yahoo.com
}

\begin{abstract}
The aims of this research are (1) analyzing social and economic vulnerability of forest and peat land fire disaster in Bengkalis Regency; (2) Mapping social and economic vulnerability of forest and peat land fire disaster in Bengkalis Regency. Research Variable is social and economic vulnerability. The data that used is primary and secondary data with survey method. Analysis method is scoring and weightings. After that classified based on the value of the score to determine the level of vulnerability. The analysis based on the head of National Agency for Disaster Management (Perka BNPB) Number 02.2012 and literatures study. The results of research show that social vulnerability of forest and peat land fire in Bengkalis Regency is medium vulnerability because it has value of social vulnerability is 0.46663 . While economic vulnerability in Bengkalis Regency is low vulnerability because economic vulnerability is 0.3333 . In addition, required mitigation that is quick and appropriate by governments of Bengkalis Regency and the local community in management of forest and peat land fire disaster.
\end{abstract}

Keywords: social and economic vulnerability, forest and peat land fire

\begin{abstract}
Abstrak
Tujuan dari penelitian ini yaitu (1) menganalisis kerentanan sosial ekonomi dalam bencana kebakaran hutan dan lahan gambut di Kabupaten Bengkalis; (2) Pemetaan kerentanan sosial ekonomi dalam bencana kebakaran hutan dan lahan gambut di Kabupaten Bengkalis. Variabel penelitian yaitu kerentanan sosial dan ekonomi. Data yang digunakan yaitu primer dan sekunder dengan metode survei. Metode analisis yang digunakan yaituskoring dan pembobotan. Setelah diklasifikasikan kemudian dilakukan penskoran untuk menentukan tingkat kerentanan. Analisis ini didasarkan pada Perka BNPB nomor 02 tahun 2012 dan literature relevan. Hasil penelitian menunjukanbahwa kerentanan sosial dalam kebakaran hutan dan lahan gambut di Kabupaten Bengkalis termasuk pada kelas kerentanan sedang karena mempunyai nilai kerentanan sosial yaitu 0,46663, sedangkan kerentanan ekonomi dalam kebakaran hutan dan lahan gambut di Kabupaten Bengkalis termasuk pada kelas kerentanan rendah karena mempunyai nilai kerentanan ekonomi yaitu 0,3333. Diperlukan upaya mitigasi yang cepat dan tepat oleh Pemerintah Kabupaten Bengkalis dan masyarakat setempat dalam rangka menghadapi kebakaran hutan dan lahan gambut.
\end{abstract}

Kata Kunci: Kerentanan sosial dan ekonomi, kebakaran hutan dan lahan gambut

\section{Introduction}

Fact proves that forests and peatlands in Indonesia recently suffered from destructions. One of the destruction was caused by forest and peat fires occurring either naturally or artificially (man-made). Some of the forest and peat fire cases arise due to human factors. In case that this problem is not soon overcome appropriately, it will lead to environmental damages.

Forest and peat fires aresome of disasters happening in Indonesia. Forest shall be any ecosystem unit in the form of spread of land containing biological natural resources dominated by trees in its environmental natural association, which either of it is inseparable (Regulation of State Minister of Living Environment Number 10 Year 2010). Peatland is a land with a thick organic soil layer made up of dead and/or decaying plant material (Adinugroho et al, 2005).

Forest and peat fires refer to a condition in which uncontrolled fires occur in forest and peatlands and thus cause destruction, as well as on their products, and result in losses (BNPB and Geospatial Information Agency, 2011). These include economic and environmental losses. The fires often lead to smoke haze which bothers surrounding communities (Kurniawan et al, 2011:6). 
Forest and peat fires occurring in Indonesia are not included as disasters caused by natural factors since almost $99 \%$ of these disasters due to man's factors, such as deliberateness and dereliction. These sort of phenomena mostly occurin peatlands and lead to an increase of greenhouse gas emissions (Saharjo et al, 2013). The existence of forest and peatland, therefore, should be preserved since in case that the forests and peatlands are not well-managed, disaster risks are more likely to rise. In regard to ICCC (Indonesian Climate Change Center) 2012, a well managed peatland will potentially give a huge contribution to reduction of greenhouse gas emissions. This is because it can save more carbons than any other forests can. However, in case that it is degraded, it will contribute bigger emissions than any other ecosystems will.

Riau is a province in Indonesia where forest and peat fires mostly occur. Impacts of the disasters, such as respiratory illness, school closing and flight delay, are very alarming for the communities. The disastersare caused by burning of peatlands which are going to be used as lands for palm oil plantation (Putri, 2004). It does not only give negative effect on people's health but it also retards their social and economic activities. The forest and peat fires in the Province of Riau commonly occur in peatlands and are resulted from land clearing factor for both plantation and HTI (Industrial Forestry or Plantation Forest) (Darjono, 2003).

Bengkalis is one of districts in the Province of Riau which is prone to forest and peat fires, and therefore, a disaster risk management is necessary to carry on. Based on hotspot maps of Riau (taken on March $5^{\text {th }}$ 2014 at 6 p.m.) created by BNPB (Indonesian National Board for Disaster Management), it is clearly seen that the second most hotspots exist in the Province of Riau with the total hotspots of 17.
On February $13^{\text {th }} 2014$, forest and peat fires occurred in several hotspots in Bengkalis. The number of hotspots spread exceeded 60 spots with total of burnt lands reaching 2000 ha. According to Head of Fire Department of BNPB, Mohammad Djalal, the fires widespread throughout Bantan, Bengkalis, Bukitbatu and Siak Kecil and they crept to deeper thick soil peat layer. They burnt approximately 300 ha of communities' plantations (Source: http:// fokusriau.com/berita-hampir-2000-hektarehutan-dan-lahanterbakar.html).

This problem, therefore, should be overcome by referring to disaster risk management. One of the best ways is to conduct a study and mapping. Analyzing and mapping economic and social vulnerability in forest and peat fires require appropriate study and therefore can be spatially transformed into a map. This is done in order to reduce or eliminate impacts of the disaster.

This research aims to: Analyze economic and social vulnerability in forest and peat landfire disasters occurred in Bengkalis, Create a mapping of economic and social vulnerability in forest and peat land fire disasters occurred in Bengkalis.

\section{Research Method}

\section{Place and Time of Research}

This research was conducted in Bengkalis from August to October 2014.

\section{Research Variables}

The research has two variables, namely social vulnerability and economic vulnerability. These variables are figured out in Table 1.

Table 1. Research Variables

\begin{tabular}{|c|c|c|c|}
\hline Variables & Parameters & Data Sources & Data Analysis \\
\hline Social & $\begin{array}{l}\text { Population } \\
\text { Density } \\
\text { Sex Ratio } \\
\text { Poverty Ratio } \\
\text { Disability Ratio } \\
\text { Age Group Ratio }\end{array}$ & $\begin{array}{l}\text { BPS Bengkalis (Bengkal is } \\
\text { Bureau of Statistics), } \\
\text { BPBD (Regional Board for } \\
\text { DisasterManagement), } \\
\text { Bengkalis District }\end{array}$ & $\begin{array}{l}\text { Analysis method is scoring } \\
\text { and weightings. After that } \\
\text { classified based on the value } \\
\text { of the score to determine the } \\
\text { level of vul nerability. }\end{array}$ \\
\hline Economic & $\begin{array}{l}\text { Productive land } \\
\text { PDRB }\end{array}$ & Landuse, reports of PDRB & \\
\hline
\end{tabular}




\section{Data Collection Method}

Data used in this research consist of primary and secondary data. Survey method was applied and survey was carried out to collect data obtained from BNPB, BPBD (Regional Board for Disaster Management), Bengkalis District, BPS Bengkalis (Bengkalis Bureau of Statistics), and Bengkalis Agriculture and Forestry Department. The data comprise description of Bengkalis in the form of numbers, products of spatial planning, Bengkalis disaster lists, reports of PDRB (Gross Regional Domestic Product), description of sub-districts in form of numbers, basic map of landuse, as well as public facility locations.

\section{Data Analysis Method}

This research applied descriptive qualitative method. Data were analyzed by weighting and scoring, and later were classified based on scores to determine the vulnerability. The analysis referred to Head of
BNPB Regulation No. 02 of 2012 and some relevant literatures. After estimation results of economic and social vulnerability were obtained, mapping was carried out. The mapping made use of GIS (Geographic Information System) software. Description on data analysis method of each variable is explained below.

\section{Social Vulnerability}

Parameters used to assess social vulnerability include population density, sex, poverty, disability, and age group ratio. Social vulnerability index was obtained from average amount of the parameters. Table 2 . clearly figures out the measurement.

\section{Economic Vulnerability}

Parameters which were used to assess economic vulnerability comprise PDRB(Gross Regional Domestic Product) and productive land width. They will be figured out in Table 3 .

Table 2. Parameters of Social Vulnerability

\begin{tabular}{|c|c|c|c|c|c|c|c|}
\hline \multirow{2}{*}{\multicolumn{2}{|c|}{ Parameters }} & \multirow{2}{*}{$\begin{array}{l}\text { Weight } \\
(\%)\end{array}$} & \multicolumn{4}{|c|}{ Classification } & \multirow[t]{2}{*}{ Score } \\
\hline & & & Lo & & Medium & High & \\
\hline \multicolumn{2}{|c|}{ Population Density } & 60 & $\begin{array}{r}<500_{1} \\
\text { per sq }\end{array}$ & $\begin{array}{l}\text { eople } \\
\text {. km }\end{array}$ & $\begin{array}{l}500-100 \text { people } \\
\text { per sq. km }\end{array}$ & $\begin{array}{l}>1000 \text { people } \\
\text { per sq. km }\end{array}$ & $\begin{array}{c}\text { Class/Max } \\
\text { score of class }\end{array}$ \\
\hline \multicolumn{2}{|l|}{ Sex Ratio (10\%) } & 40 & $<2$ & & $20-40 \%$ & $>40 \%$ & \\
\hline \multicolumn{8}{|c|}{ Poverty Ratio (10\%) } \\
\hline \multicolumn{8}{|c|}{$\begin{array}{l}\text { Age Group Ratio } \\
(10 \%)\end{array}$} \\
\hline$=$ & $\begin{array}{r}0.6 * \\
+(C\end{array}$ & $\begin{array}{r}\begin{array}{r}\log \\
\text { population } \\
0.01\end{array} \\
\log \left(\frac{1}{0 .}\right. \\
1 * \text { disabi }\end{array}$ & $\left.\frac{(n s i t y}{)}\right)$ & $+(0.1$ & sex ratio $)+(0$ & I * poverty ra & \\
\hline
\end{tabular}

Source: Perka BNPB No. 02 year 2012.

Table 3. Parameters of Economic Vulnerability

\begin{tabular}{|c|c|c|c|c|c|}
\hline \multirow[t]{2}{*}{ Parameter } & \multirow{2}{*}{$\begin{array}{c}\text { Value } \\
(\%)\end{array}$} & \multicolumn{3}{|c|}{ Class (million rupiahs) } & \multirow[t]{2}{*}{ Score } \\
\hline & & Low & Middle & High & \\
\hline $\begin{array}{l}\text { Productive } \\
\text { land }\end{array}$ & 60 & $<50$ & $50-200$ & $>200$ & $\begin{array}{l}\text { Class/Class } \\
\text { Maximum }\end{array}$ \\
\hline PDRB & 40 & $<100$ & $100-300$ & $>300$ & Score \\
\hline
\end{tabular}

Source: Perka BNPB No. 02 year 2012. 


\section{Results and Discussion}

\section{General Description of Bengkalis}

Bengkalis is astronomically situated on $2^{07} 7^{\prime} 37.2^{\prime \prime}-$ 0055'33.6" N and 1005 '57.6" - 102030'25.2" E. With the total area of $7,773.93 \mathrm{~km}^{2}$, it is made up of islands and sea. Bengkalis has 8 sub-districts, consisting of 102 villages. Bengkalis Sub-district has the most villages, totally 20 villages or regencies; meanwhile Rupat Utara Sub-district has the fewest villages with the total of 5 villages/regencies (Bengkalis Bureau of Statistics, 2013). Map of Bengkalis administrative area is presented in Figure 1.

\section{Social Vulnerability in Forest and Peat Fire Disasters in Bengkalis Regency}

Disaster risk appears when danger influences physical, social, economic, and environmental vulnerability (ISDR, 2005: 1). Vulnerability is a human characteristic or group and situation that may affect their capacity to anticipate, cope, survive, and recover from the effects of natural hazards (Sagala and Yasaditama, 2012). In this study, which will be analysis are the social and economic vulnerability.
Social vulnerability analysis is a part of study on disaster risk. Generally, social vulnerability has different definitions. According to Sumekto (2011:31), social vulnerability is the vulnerability level prediction toward human security when a disaster occurs in an area. Social vulnerability is the potential impact from the incident occurring to vulnerable group of society, such as poor people, household, single parents, pregnant women, disabled people, children, and old people. Vulnerability level can be considered from the factor of public awareness to risks, the group's capability to cope with the disaster, and the institutional hierarchical status which is set to help the society to ward off the disaster (Western, et.al, 2001).

Social vulnerability in forest and peat fires is a condition which depicts society's vulnerability level toward safety if forest and peat fires occur in an area. Social vulnerability analysis of Bengkalis residents in forest and peat fires is based on some parameters, comprising the population density and the ratio of sex, poverty, disabled people, and age (Head of BNPB Regulation Number 02 Year 2012).

Social vulnerability parameters are closely related to human aspects. Human is one of vulnerable aspects to the disaster. Practically, every single social

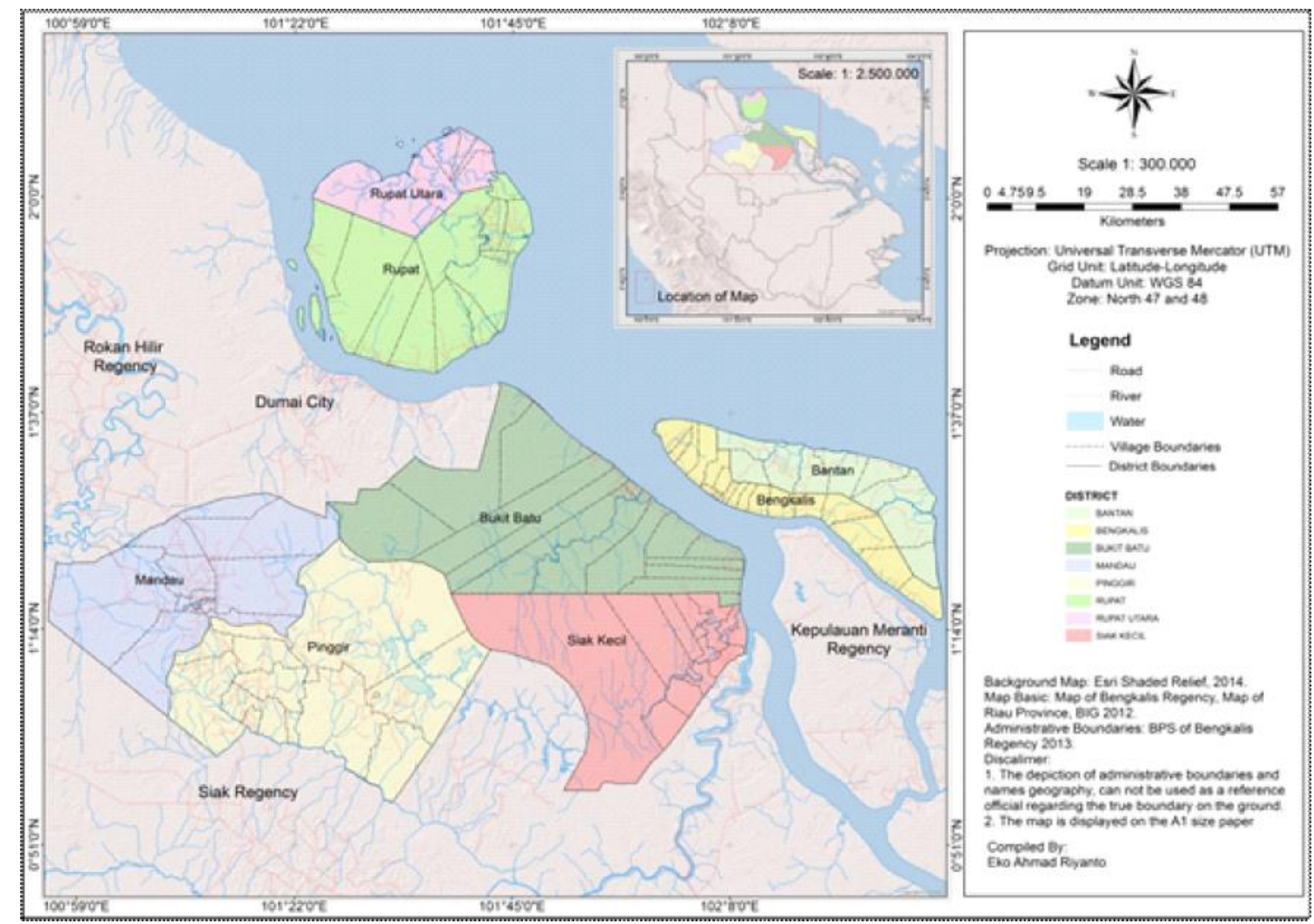

Figure 1. Administrative map of Bengkalis Regency 
vulnerabilityparameter has different weight and score. Population density parameter is wieghtedat the highest score $60 \%$, while other parameters are weightedat $10 \%$ for each (see Table 3 ). According to Giyarsih et.al (2014: 59), the population density has the highest weight because the level of population density influences the level of disaster risk impact experienced by society in an area. The higher the population density is, the higher the citizen vulnerability level to the disaster will be, and vice versa.

The social vulnerability value for each area in Bengkalis towards forest and peat fires is obtained by giving score and weightof each parameter. The total social vulnerability value is obtained by adding up the results score and weight. Vulnerability class value is divided into three categories, including: (1) low: scored 0-0.33; (2) medium: scored 0.333-0.666, and (3) high: scored $0.666-1$. The counting result is presented in Table 4.

According to the calculation of the social vulnerability in forest and peat fires, it is found that social vulnerability in Bengkalis regency belongs to medium category, with the social vulnerability value of 0.46663 (see Table 4). It is also found that the 8 sub-districts in Bengkalis regency are considered to have medium vulnerability level. To give clearer illustration, social vulnerability in Bengkalis regency is displayed in figure 2.

The level (high or low)of social vulnerability in Bengkalis in forest and peat fires is attributable to population density, sex ratio, poverty ratio, disabled people ratio, and age group ratio. From further examination on the result of social vulnerability (see figure 2), it is found that all areas in Bengkalis have medium vulnerability which are signed with yellow for the vulnerability index. Besides influenced by the factors mentioned earlier, the level of social vulnerability is affected by other factors and one of them is sex. Generally, female citizens are more vulnerable to harm compared to male ones. It deals with the physical factors. Zhang and You (2013) conducted a research on the social vulnerability in Huaihe river valley (China). The study result reveals that the vulnerability of most citizens depends on sex and quality of the society.

\section{Economy Vulnerability in Forest and Peat Fire Disaster in Bengkalis}

Generally,there are a number of different definitions of economic vulnerability. According to Sumekto (2011: 31), economic vulnerability is a condition depicting or stimulating the amount of lost or the damage of facilities and economic activities due to the existing danger in a certain area. According to Western et.al., economic vulnerability is potential impact caused by dangerposing a threat to asset, process, and several economic sectors, for example, business disturbance, secondary effect such as poverty increase and the jobless.

Economic vulnerability is a condition describing the potential amount of loss, disturbance, the facility damage, process, and economy activities in an area which is caused by danger. The parameters to consider economic vulnerability level are productive fields and GDRP (Gross Domestic Regional Product-Produk Regional Domestik Bruto/ $P D R B)$. The economic vulnerability parameters are closely related to economical aspects of a society

Table 4. Social Vulnerability in Bengkalis Regency in Forest and Peatland Fire

\begin{tabular}{llccccccc}
\hline No. & District & $\begin{array}{c}\text { Population } \\
\text { density } \\
\left(\mathrm{Km}^{2}\right)\end{array}$ & $\begin{array}{c}\text { Sex } \\
\text { Ratio } \\
(\%)\end{array}$ & $\begin{array}{c}\text { Poverty } \\
\text { Ratio } \\
(\%)\end{array}$ & $\begin{array}{c}\text { Disable } \\
\text { People } \\
\text { Ratio } \\
(\%)\end{array}$ & $\begin{array}{c}\text { Age } \\
\text { group } \\
\text { Ratio } \\
(\%)\end{array}$ & $\begin{array}{c}\text { Total } \\
\text { Score }\end{array}$ & $\begin{array}{c}\text { Vulnerability } \\
\text { Class }\end{array}$ \\
\hline 1 & Mandau & 249 & 108 & 6,74 & 0.019 & 35,44 & 0.4333 & medium \\
2 & Pinggir & 35 & 107 & 6,74 & 0.074 & 35,44 & 0.4333 & medium \\
3 & Bukit Batu & 28 & 105 & 6,74 & 0.539 & 35,44 & 0.4333 & medium \\
4 & Siak Kecil & 26 & 107 & 6,74 & 0.74 & 35,44 & 0.4333 & medium \\
5 & Rupat & 35 & 106 & 6,74 & 0.318 & 35,44 & 0.4333 & medium \\
6 & North & 22 & 107 & 6,74 & 1.259 & 35,44 & 0.4333 & medium \\
& Rupat & & & & & & & \\
7 & Bengkalis & 146 & 104 & 6,74 & 0.365 & 35,44 & 0.4333 & medium \\
8 & Bantan & 86 & 104 & 6,74 & 0.473 & 35,44 & 0.4333 & medium \\
\hline
\end{tabular}


and an area. Each parameter has different weightand score. Productive field parameter is weighted $60 \%$, while the GRDP parameter is valued $40 \%$ (see Table $3)$.

Each economic vulnerability level in Bengkalis in forest and peat fires is obtained through scoring and weighting each parameter. The total value of economic vulnerability is measured by calculating the score and weight. To give clearer picture on the economic vulnerability calculation, see Table 5.

According to the research finding, it is obtained that GRDP value in Bengkalis in 2012 was based upon the price in demand amounting to IDR 107,962,021.80 and fixed price amounting to IDR 3,963,000,000. Meanwhile, the value of productive agricultural field in Bengkalis is IDR 949,439.45 and the mining and excavating value is IDR $25,137,917.33$.

Table 5. Economy Vulnerability in Bengkalis Regency in Forest and Peatland Fire

\begin{tabular}{cccccccccc}
\hline No. & District & GDRP (Rp) & Value & Score & $\begin{array}{c}\text { Productive } \\
\text { Land (Rp) }\end{array}$ & Value & Score & $\begin{array}{c}\text { Total } \\
\text { Score }\end{array}$ & Class \\
\hline 1 & Mandau & $13,030,833$ & 0.4 & 0.333 & $3,145,913,89$ & 0.6 & 0.333 & 0.333 & Low \\
2 & Pinggir & $34,791,700$ & 0.4 & 0.333 & $8,399,439,41$ & 0.6 & 0.333 & 0.333 & Low \\
3 & $\begin{array}{l}\text { Bukit } \\
\text { Batu }\end{array}$ & $15,679,200$ & 0.4 & 0.333 & $3,785,284,72$ & 0.6 & 0.333 & 0.333 & Low \\
4 & & & & & & & & & \\
& Siak & $10,316,719$ & 0.4 & 0.333 & $2,490,670,37$ & 0.6 & 0.333 & 0.333 & Low \\
& Kecil & & & & & & & & \\
5 & Rupat & $12,459,265$ & 0.4 & 0.333 & $3,007,925,50$ & 0.6 & 0.333 & 0.333 & Low \\
6 & North & $8,736,150$ & 0.4 & 0.333 & $2,109,088,16$ & 0.6 & 0.333 & 0.333 & Low \\
& Rupat & & & & & & & & \\
7 & Bengkalis & $7,144,600$ & 0.4 & 0.333 & $1,724,854,92$ & 0.6 & 0.333 & 0.333 & Low \\
8 & Bantan & $5,899,160$ & 0.4 & 0.333 & $1,424,179,82$ & 0.6 & 0.333 & 0.333 & Low \\
\hline Bengkalis & $107,962,021$ & & & $26,087,356,78$ & & & & Low \\
Regency & & & & & & & & \\
\hline
\end{tabular}

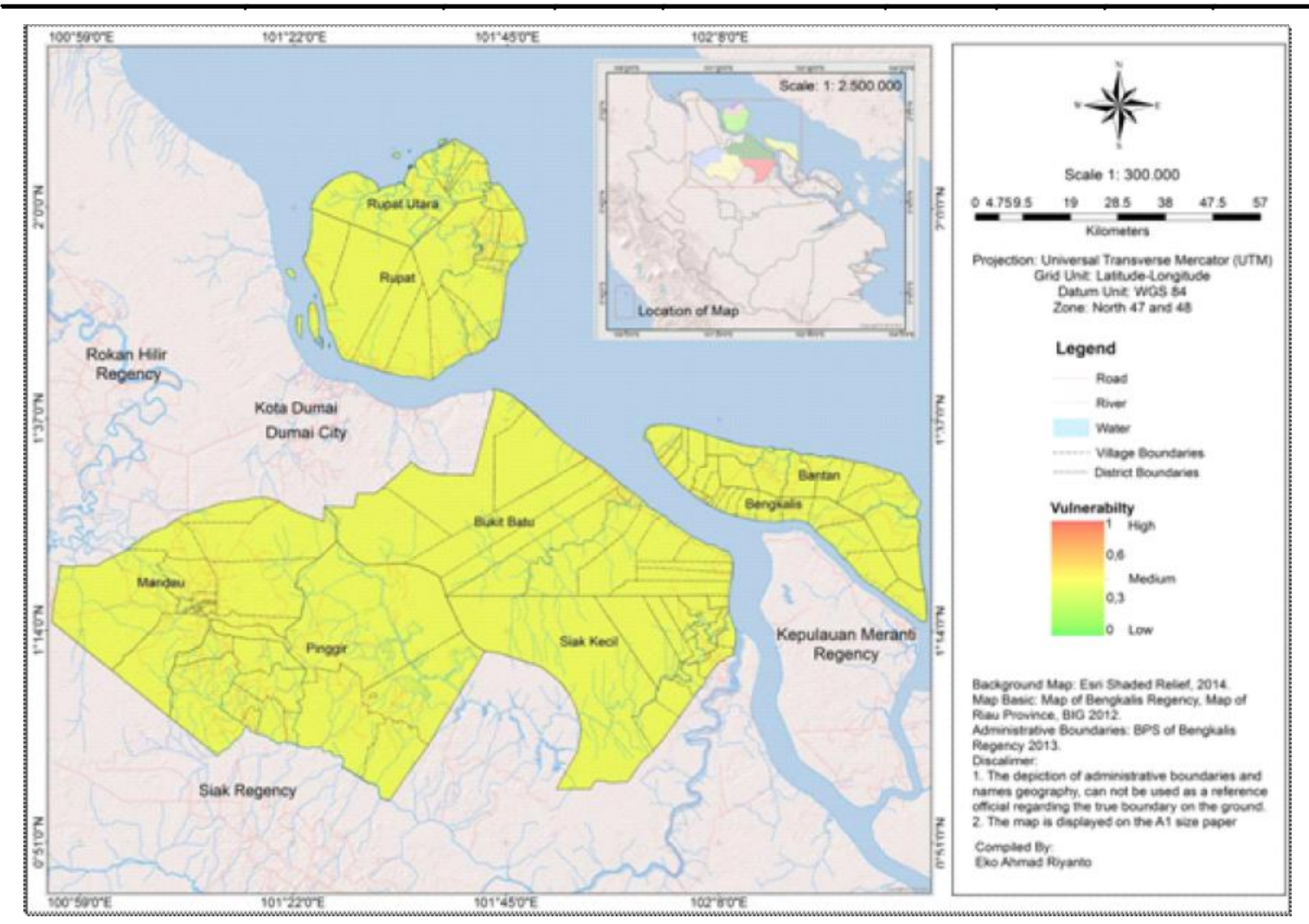

Figure 2. Map of Social Vulnerability 
Based on the valuation result of the economic vulnerability in Bengkalis, it is found that the economic vulnerability in Bengkalis in forest and peat fires belongs to low level since the economic vulnerability value is 0.333 (see Table 3.3). It can be concluded that all sub-districts in Bengkalis are considered to low level vulnerability. For the clearer illustration on the economic vulnerability in Bengkalis, please see Figure 3.

Related to forest and peat fires, Bengkalis has a low economic vulnerability value. The fact proves that, economically, the area has low vulnerability level when forest and peat fires occur. The level of economic vulnerability value in Bengkalis is influenced by productive land factors and GDRP. If examined based on the economic vulnerability mapping (see Figure 3.3), it is found that all areas in Bengkalis have low vulnerability which is marked with green vulnerability index.

An area witha number of poor residents will be likely to be more vulnerable to a danger. This is because the residents are considered to lack of financial ability to do prevention or disaster mitigation efforts (BNBP, 2010: 28). An area with many destitute residents, economically, will be more vulnerable to a danger, compared to wealthy residents. It is assumed that destitute people economically have low-financial ability to mitigate disasters.High social vulnerability of society leads them to be vulnerable. The lower the social and economic vulnerability of a society is, the more the society is able to face a disaster and continue their lives.

\section{Conclusions and Recommendations}

a. Social vulnerability in forest and peatland fires in Bengkalis is included in the medium class because the value of social vulnerability is 0.46663 .

b. Economic vulnerability in forest and peatland fire in Bengkalis is included in low class because the value of economic vulnerability is 0.3333 .

Based on the results, it is recommended to:

a. Further research on the analysis of economic and social vulnerability of forest and peatland fire is very important to do and develop with the addition of indicators and detailsof the analysis unit.

b. Mapping and analysis of social and economic vulnerability in a forest and peatland fire needs to be updated on an ongoing basis because this disaster is dynamic.

c. Quick and accurate mitigation efforts are needed by Bengkalis Government and the local community in order to deal with forest and peat landfire.

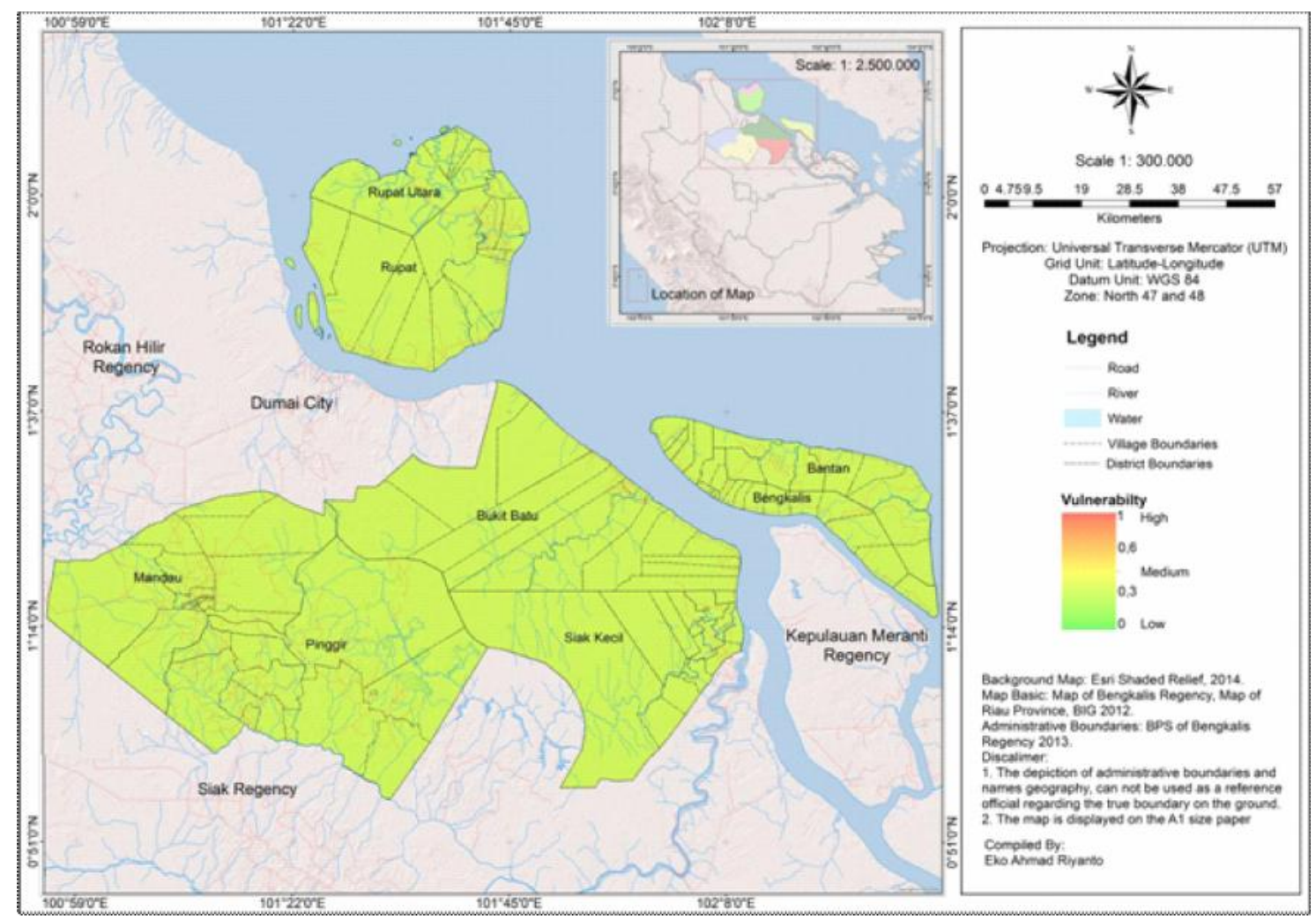

Figure 3. Map of Economic Vulnerability 


\section{References}

Adinugroho, W. C., I N.N. Suryadiputra, Bambang Hero Saharjo dan LabueniSiboro. (2005)Panduan Pengendalian Kebakaran Hutan dan Lahan Gambut. Proyek Climate Change, Forests and Peatlands in Indonesia. Wetlands International-Indonesia programme dan Wildlife Habitat Canada. Bogor. Indonesia.

BNPB.(2010)Rencana Nasional Penanggulangan Bencana 2010-2014. Jakarta: Direktorat Mitigasi BNPB.

BNPB dan BIG.(2012)Atlas Kebencanaan Indonesia 2011.Badan Nasional Penanggulangan Bencana \& Badan Informasi Geospasial.

BPS Kabupaten Bengkalis.(2013) Kabupaten Bengkalis dalam Angka 2013.Bengkalis: Badan Perencanaan Pembangunan Daerah Kabupaten Bengkalis.

ICCC. (2012)Lembar Fakta. November 2012. www. iccc-network.net.

Darjono.(2003) Pengalaman Penegakan Hukum yang Berkaitan dengan Kebakaran di Areal Perkebunan dan HTI Rawa Gambut.Dalam Prosiding Semiloka. Editor: Suyanto. Chokkalingan, U., Wibowo, P. Diterbitkan: CIFOR.

Giyarsih, S.R., Listyaningsih, U., Budiani, S.R. (2014) Aspek Sosial Banjir Lahar. Yogyakarta: Gadjah Mada University Press.

Irawan, F. (2013)Rencana Kontinjensi Nasional Menghadapi Ancaman Bencana Asap Akibat Kebakaran Hutan dan Lahan. Jakarta: BNPB.

ISDR. (2005) Hyogo Framework for Action 2005-2015: Building the Resilience of Nations and Communities to Disasters. World Conference on Disaster Reduction 18-22 January 2005, Kobe, Hyogo, Japan.

Kurniawan, L., Yunus, R., Amri, MR. Pramudiarta, N. (2011)Indeks Rawan Bencana Indonesia. Jakarta: BNPB.

Peraturan Menteri Negara Lingkungan Hidup No. 10 Tahun 2010, tentang mekanisme pencegahan pencemaran dan/ atau kerusakan lingkungan hidup yang berkaitan dengan kebakaran hutan dan/atau lahan).

Perka (Peraturan Kepala) BNPB (Badan Nasional Penanggulangan Bencana) Nomor 02 Tahun 2012, Tentang:Pedoman Umum Pengkajian Risiko Bencana.

Putri, R. (2004) Bencana Tahunan Kabut Asap Riau dalam Pandangan Politik Hijau.Jurnal Phobia, Journal Issue: vol. 1/ No.03/ 20 March 2014.

Sagala, S.A.H dan Yasaditama, H.I. 2012. Analisis Bahaya dan Resiko Bencana Gunungapi Papandayan (Studi Kasus: Kecamatan Cisurupan, Kabupaten Garut. Jurnal: Forum Geografi, Vol. 26, No. 1, Juli 2012: 1 16.

Saharjo, B.H., Syaufina, L., Putra, E.I., Bahruni., Sunarti, E., Nurhayati A.D. (2013) Penanggulangan Kebakaran Hutan dan Lahan di Indonesia. Prosiding Seminar Nasional Riset Kebencanaan, Mataram, 8-10 Oktober 2013.

Seminar Nasional: Pengembangan Kawasan Merapi: Aspek Kebencanaan dan Pengembangan Masyarakat Pasca Bencana.(2011)Pengurangan Risiko Bencana melalui Analisis Kerentanan dan Kapasitas Masyarakat dalam Menghadapi Bencana.Sumekto, D.R. Yogyakarta: UII.

Westen, C.J. Van.., Alkema, D., Damen, M.C.J., Kerle, N., Kingma, N.C. (2011)Multi Hazard Risk Assessment. United Nation University-ITC School on Disaster Geoinformation Management (UNUITC DGIM).

Zhang, YL dan You, W.J. (2013) Social Vulnerability to Foods: a Case Study of Huaihe River Basin.Journal: Nat Hazards (2014) 71:2113-2125. DOI 10.1007/s 11069-013-0996-0. Received: 1 October 2013/ Accepted: 7 December 2013/ Published online: 19 December 2013.

http://fokusriau.com/berita-hampir-2000-hektare-hutan-dan-lahanterbakar.html. 